\title{
Correlative inhibition and dormancy in root buds of leafy spurge (Euphorbia esula) ${ }^{1}$
}

\author{
SCOTT J. NISSEN and MICHAEL E. FOLEY
}

The authors are Grad. Res. Asst. and Asst. Prof., Plant and Soil Sci. Dep., Montana State Univ., Bozeman, MT 59717, respectively.

\begin{abstract}
:
Root buds of leafy spurge (Euphorbia esula L. \#² EPHES) were found to be quiescent during most of the growing season due to correlative inhibition rather than innate dormancy. Excised root buds taken from plants that were fully flowering showed reduced elongation, indicating a period of innate dormancy. This innate dormancy could be eliminated by chilling plants for 8 days at $4^{\circ} \mathrm{C}$. Root buds from plants showing late summer regrowth were no longer innately dormant. IAA (indole-3-acetic acid) and NAA (1-napthaleneacetic acid) completely inhibited the growth of excised leafy spurge root buds at concentrations of $10^{-3}$ and $10^{-5} \mathrm{M}$, respectively. A significant increase in root bud elongation was produced by $1 \mathrm{mM}$ TIBA (2,3,5-triiodobenzoic acid) applied to stem and root tissue. These data provide further evidence for the involvement of IAA in correlative control of root bud growth in leafy spurge.
\end{abstract}

\section{Additional index words:}

Developmental arrest, exogenous auxins, stratification.

\footnotetext{
${ }^{1}$ Received for publication March 3, 1986, and in revised form June 30, 1986. Contribution of the Montana Agric. Exp. Stn., Montana State Univ., Bozeman, MT 59717. Published with the approval of the Director, Montana Agric. Exp. Stn., as J. Ser. No. J1821.

${ }^{2}$ Letters following this symbol are a WSSA-approved computer code from Composite List of Weeds, Weed Sci. 32, Suppl. 2. Available from WSSA, 309 West Clark Street, Champaign, IL 61820.
} 


\section{Introduction}

Leafy spurge was introduced into the United States from Europe in soil used as ship ballast and in contaminated grain brought from Russia by Mennonite immigrants (7). This perennial, herbaceous weed has since spread to infest 26 states and six Canadian provinces. The North American infestation was estimated at 1.1 million hectares in 1979 (20). Leafy spurge is well suited to semiarid rangeland in Montana, Wyoming, North Dakota, and South Dakota in these states, leafy spurge is considered the most serious range weed problem, while in other states it finds suitable habitat along roadsides and in waste areas.

Leafy spurge persists despite all efforts at cultural, biological, and chemical control. One characteristic that contributes to its persistence is an extensive root system that possesses numerous adventitious buds. New shoots can be produced by both crown and root buds. Crown buds develop at the soil surface each fall and the following spring they rapidly elongate to produce that season's shoot growth. Root buds are located along the entire length of the root system, although the majority occur in the upper $30 \mathrm{~cm}$ of the soil profile (4). These buds do not grow unless the current season's topgrowth is removed by tillage, grazing, or chemical treatments. A significant increase in shoots $/ \mathrm{m}^{2}$ can result from root bud growth after shallow tillage or chemical treatments, which do not have a soil residue (26). The term "bud dormancy"3 has been used to describe the developmental arrest of root buds. However, the distinction should be made between dormancy within the bud (innate dormancy) (24) and dormancy enforced by the main shoot (correlative inhibition) (12).

The physiological processes involved in the developmental arrest of root buds are not well understood. Research has shown that root bud growth in certain perennial plants is influenced by phytohormones, chilling temperatures, plant nutrient status, and internal water relations $(14,17,18,23)$. Shoot axillary bud inhibition is more clearly defined. Ethylene production induced by indole-3-acetic acid (IAA) appears to be responsible for correlative inhibition of axillary buds $(2,10,29)$. Ethylene levels at the leaf axis have been shown to drop dramatically after removal of the shoot apex, and complete release of axillary buds has been demonstrated by direct application of ethylene synthesis inhibitors $(2,28,29)$.

The ability of leafy spurge to produce new shoots from root buds has long been recognized as a major factor contributing to this plant's persistence $(3,4,8,17,18,23)$. Developing a more complete understanding of the mechanisms involved in control of root bud growth may provide insights to aid in control of this plant and other perennial weeds. The objectives of this study were to determine: a) if innate dormancy or correlative inhibition occurred in root buds at various leafy spurge growth stages, b) the effects of chilling temperatures on root bud elongation, and c) the influence of exogenously applied auxins (IAA, NAA) on root bud growth.

\footnotetext{
${ }^{3}$ Dosland, J. G. 1969. Studies relating to bud dormancy and auxin catabolism in Euphorbia esula L. Ph.D. Thesis, North Dakota State Univ., Fargo, ND.
}

Page 2 of 10 


\section{Materials and methods}

\section{Plant material}

Leafy spurge plants used in these experiments were propagated by root cuttings from a single plant. Root cuttings were grown in cone-shaped pots $4 \mathrm{~cm}$ in diameter at the top, tapering to a diameter of $1 \mathrm{~cm}$ over a $21-\mathrm{cm}$ length $\left(155-\mathrm{cm}^{3}\right.$ volume). Pots were filled with a $50: 50(\mathrm{v} / \mathrm{v})$ mixture of greenhouse potting soil $(58 \%$ sand, $18 \%$ silt, $24 \%$ clay, and $2.8 \% \mathrm{OM}$ ) and sand. Pots were placed in a growth chamber set at a constant temperature of $25^{\circ} \mathrm{C}$ with photosynthetic photon flux density (PPFD) of $150 \mu \mathrm{E} \cdot \mathrm{m}^{-2} \cdot \mathrm{s}^{-1}$ and a 16 -hour photoperiod. After 3 months, root cuttings had developed into plants with $35 \mathrm{~cm}$ of topgrowth and root systems that filled the entire volume of rooting media. The plants were transplanted to large tubes $(0.1-\mathrm{m}$ diameter by $1-\mathrm{m}$ length) made of polyvinyl chloride (PVC) and filled with the same mixture of potting soil and sand. Plants were grown under greenhouse conditions at a constant temperature of $25 \pm 3^{\circ} \mathrm{C}$. Natural light was supplemented during winter months with banks of incandescent and fluorescent lights providing a PPFD of $200 \mu \mathrm{E} \cdot \mathrm{m}^{-2} \mathrm{~s}^{-1}$ and extending the photoperiod of 12 hours.

\section{Root bud growth potential}

Initial studies were conducted to determine the relationship of bud size and location to shoot growth potential. Greenhouse-grown plants were removed from PVC tubes and root systems washed free of soil with tapwater. Root buds were selected at random from $1-\mathrm{m}$-long roots starting $10 \mathrm{~cm}$ below the crown. Initial bud size, distance of the selected bud from the crown, and diameter of the root at the selected bud were determined. After measurement, the root was cut $1 \mathrm{~cm}$ above and $1 \mathrm{~cm}$ below the measured bud. Root pieces were then placed horizontally in $32-$ by $24-$ by $9-\mathrm{cm}$ germination boxes filled to a depth of $1 \mathrm{~cm}$ with sterile sand. The sand had previously been saturated with distilled water. Root segments were pushed into the sand so that cut ends of roots were in contact with moist sand. A total of 15 to 25 root sections, each containing a single root bud, were placed in each germination box and incubated in the dark at $20^{\circ} \mathrm{C}$ for 15 days. Distilled water was added every 3 days to maintain sand in a saturated condition. Root bud elongation was measured at the end of the 15-day period and compared by regression analysis to initial bud size, distance from the crown, and root diameter. The growth response of 891 root buds collected from 35 different plants was determined.

\section{Plant growth stage}

The occurrence of correlative inhibition and innate dormancy during the yearly growth cycle of leafy spurge was determined during the 1984 and 1985 growing seasons. On April 2, 1984, and April 5, 1985, one-year-old plants grown in 1-m PVC tubes were moved from the greenhouse to the Post Agronomy Farm, Bozeman, MT. The topgrowth was removed and the PVC tubes placed in holes in the ground just larger than the diameter of the tubes. The holes were deep enough so that the top of the tubes were even with the soil surface. Root buds were collected on May 15, June 2, June 14, June 25, and August 23, 1984, and May 1, May 20, June 5, June 18, and August 15, 1985. These sam- 
pling dates correspond to five growth stages: 1) spring vegetative growth, 2) bract formation, 3) early flowering, 4) full flower, and 5) late summer regrowth, respectively. Two plants at each growth stage were removed from the PVC tubes and roots washed free of soil with tapwater. Root buds were removed from the parent root system by cutting the root $1 \mathrm{~cm}$ above and $1 \mathrm{~cm}$ below the selected bud. The initial root bud length was determined immediately following removal from the parent root system. Root segments were incubated in sterile sand as previously described. Root bud elongation was measured after 15 days and the initial length subtracted. Treatments consisted of 20 to 25 root buds per treatment, and results from the 2 years were combined for statistical analysis. Mean elongation at each growth stage was compared by Newman-Keul's sequential studentized range test.

\section{Chilling temperatures}

An experiment was conducted to determine the effect of chilling temperatures on root bud growth. The experiment was conducted in the same manner as the one previously described. Paired plants were selected on approximately the same sampling dates as before, representing the same five growth stages. Root buds were collected immediately from one plant, while the other plant, still in the PVC tube, was placed in a cold room at $4^{\circ} \mathrm{C}$ for 8 days. Root buds were collected as before, following the 8-day chilling treatment. Elongation was measured every third day over a 15-day period, and the cumulative growth was compared by analysis of variance. Treatments consisted of 15 to 20 root buds per treatment. The experiment was conducted for 2 years and the data combined.

\section{Exogenous auxins}

The influence of exogenous IAA and NAA on root bud growth was examined utilizing 2-cm root sections containing a single root bud. IAA concentrations of $0,10^{-3}, 10^{-5}$, $10^{-7}, 10^{-9}$, and $10^{-11} \mathrm{M}$ and NAA concentrations of $0,10^{-3}, 10^{-5}, 10^{-7}, 10^{-9}, 10^{-11}$, and $10^{-13}$ $\mathrm{M}$ in $25 \mathrm{mM}$ 2( $N$-morpholino)ethane sulfonic acid (MES) buffer ( $\mathrm{pH} 6.1$ ) were used. Plastic test tubes were filled with $1.5 \mathrm{ml}$ of solution and sealed with three layers of parafilm. A small hole was made in the parafilm and the proximal end of the root section inserted $0.5 \mathrm{~cm}$ into the buffered auxin solution. Root sections with attached test tubes were placed in germination boxes filled with sterile sand and incubated for 9 days under conditions previously described. Ten root buds were used per treatment and the experiment was repeated four times. Root bud growth at each auxin level was expressed as a percent of the control, and data from four experiments were combined. Treatment means were compared by LSD.

\section{TIBA experiments}

TIBA, an IAA translocation inhibitor (19), was used to further investigate the role of IAA in correlative inhibition of leafy spurge root buds. Whole plants growing in coneshaped pots under growth chamber conditions were used. (See Plant Materials section.) Plants were first removed from pots and roots washed free of soil with tapwater. The number of root buds longer than $3 \mathrm{~mm}$ was determined and expressed as a percent of the 
total number of root buds present. Plants were then reported in sterile sand. TIBA was applied continuously to stem tissue that had been abraded with 600 grit silicon carbide powder. A small plastic vial was placed around the abraded stem tissue, sealed at the bottom and sides with petroleum jelly, and then filled with water or a 1-mM TIBA solution. The top of each vial was sealed around the plant stem with paraffin. Root treatment consisted of watering with $10 \mathrm{ml}$ of $1 \mathrm{mM}$ TIBA daily for five consecutive days. A third treatment combined stem and root application. Plants were maintained under growth chamber conditions previously described. Ten days after the first treatment application, plants were removed from pots and root bud length was remeasured. The number of root buds longer than $3 \mathrm{~mm}$ was determined and expressed as a percent of total root buds present. The difference between starting and ending values was expressed as a percent increase. The percent increase in root buds longer than $3 \mathrm{~mm}$ for control and TIBA-treated plants was compared by Newman-Keul's sequential studentized range test. The number of root buds per plant ranged from 15 to 40, and five plants were used per treatment. The experiment was repeated three times with the same qualitative but somewhat different quantitative results. The results of a typical experiment are shown.

Table 1. Average correlation coefficient (r) from 35 regressions comparing the growth response of leafy spurge root buds to size and positional differences.

\begin{tabular}{lccc}
\hline & Growth $^{\mathrm{a}}$ & Size $^{\mathrm{b}}$ & Distance $^{\mathrm{c}}$ \\
\hline Size $^{\mathrm{b}}$ & 0.31 & $\ldots$ & $\ldots$ \\
Distance $^{\mathrm{c}}$ & -0.22 & -0.31 & $\ldots$ \\
Diameter $^{\mathrm{d}}$ & 0.07 & 0.11 & -0.48 \\
\hline
\end{tabular}

${ }^{\mathrm{a}}$ Growth refers to the elongation of root buds excised from leafy spurge roots system and allowed to grow for 15 days.

${ }^{\mathrm{b}}$ Size refers to the initial length of the root buds before removal from the intact root system.

${ }^{\mathrm{c}}$ Distance is the distance of the bud from the crown.

${ }^{\mathrm{d}}$ Diameter is the root diameter at the root bud.

\section{Results and discussion}

\section{Root bud growth potential}

There was no significant relationship between root bud growth and initial bud size, distance of the bud from the crown, and root diameter at the root bud. Table 1 shows the average of 35 simple correlation coefficients determined between measured parameters. No significant P-values were found between root bud growth and other variables. The potential of each root bud to produce a new shoot appeared to be unrelated to size or location on the root system. These results are consistent with those of other investigators working with leafy spurge root buds (23) and shoot bud production on root systems of rush skeletonweed (Chondrilla juncea L. \#CHOJU) (14). 


\section{Growth stage}

Root buds taken from plants in the first three growth stages elongated rapidly after removal from the root system (Table 2). Root buds appeared to have no innate dormancy during these periods and were quiescent because of correlative inhibition by the main shoot. When buds were taken from plants that were fully flowering, root bud elongation was considerably less, indicating the presence of innate dormancy. Once late-summer regrowth occurred, the period of innate dormancy appeared to be over. A wide variety of perennial plants show the same seasonal patterns in adventitious shoot production $(5,6$, $9,13,16,23,25,27)$. It has been suggested that the reduction in root bud elongation associated with flowering in some plants is related to increased IAA levels in root tissue, a direct result of IAA translocated from the shoot $(9,25,27)$. Early attempts were successful in demonstrating a significant increase in root-extractable IAA associated with flowering in European aspen (Populus tremula L.) (9) and Quaking aspen (Populus tremuloides L.) (25). If high IAA levels during flowering imposed an innate dormancy, increased root bud elongation in the fall might be the result of significantly lower root IAA levels. The growth of numerous axillary buds in late summer and fall (15) would indicate that apical dominance is reduced because of lowered IAA translocation from shoot apex. Marston (16) has demonstrated that in raspberries, plant propagation can be successful during summer dormancy period if the shoot meristem and axillary buds are removed 3 weeks prior to removal of root cutting. This treatment would reduce endogenous IAA levels in the root. McIntyre $(17,18)$ has suggested the main factor contributing to growth inhibition of leafy spurge root buds is competition between root buds and above ground shoot for available resources such as water and nitrogen. However, the period of innate dormancy associated with full flowering indicates that during part of the plant's growth cycle root bud inhibition is controlled by endogenous factors.

Table 2. Average elongation of leafy spurge root buds on 2 -cm root sections 15 days after removal from plants at five growth stages ${ }^{\mathrm{a}}$.

\begin{tabular}{lc}
\hline Plant growth stage & Root bud growth ${ }^{\mathrm{b}}$ \\
\hline & $(\mathrm{mm})$ \\
Vegetative & $44.6 \mathrm{~b}$ \\
Bract formation & $48.6 \mathrm{~b}$ \\
Early flowering & $51.7 \mathrm{~b}$ \\
Full flowering & $11.5 \mathrm{a}$ \\
Late summer regrowth & $65.6 \mathrm{c}$ \\
\hline${ }^{\mathrm{a}}$ Combination of data from 1984 and 1985 growing season. \\
${ }^{\mathrm{b}}$ Means followed by the same letter are not significantly different at $\mathrm{P}=0.05$ according to Newman-Keul's \\
sequential studentized range test.
\end{tabular}

Page 6 of 10 


\section{Chilling temperatures}

Many plants require a period of chilling temperatures before vegetative buds can resume growth in spring (21). Preliminary experiments indicated that root buds that failed to elongate after release of correlative inhibition could be induced to grow if plants were first chilled at $4^{\circ} \mathrm{C}$ for 8 days. At four of five growth stages examined there was no significant response to chilling treatments. Root bud elongation of chilled and nonchilled plants at the vegetative, bract, early-flower, and late-summer regrowth stages have been averaged together and results are shown in Figure 1a. Root bud elongation was significantly increased by chilling plants that were in full flower (Figure 1b). Chilling temperatures apparently reduced innate dormancy, which occurred during that growth stage. No fall dormancy was present in root buds, since root buds from plants in late-summer regrowth stage elongated rapidly without chilling treatments. Dosland ${ }^{3}$ found that leafy spurge crown buds had a definite fall dormancy period, which was overcome by an accumulation of days with average temperatures below $5^{\circ} \mathrm{C}$. These data indicate that crown and root buds are somewhat different physiologically.

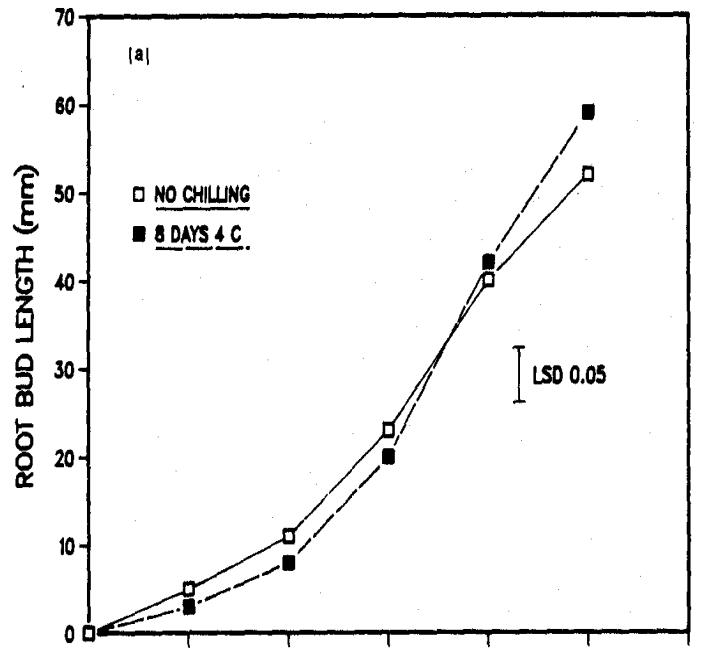

Figure 1. Elongation of leafy spurge root buds excised from plants with and without exposure to chilling temperatures. Root buds were removed from plants in various growth stages: (a) average of response from plants in vegetative, bract formation, early-flower and late-summer regrowth stages; (b) response from plants in full flower. Intact plants were chilled at $4^{\circ} \mathrm{C}$ for 8 days and root buds excised on 2cm-long root sections. Data represent average of 1984 and 1985 field seasons.

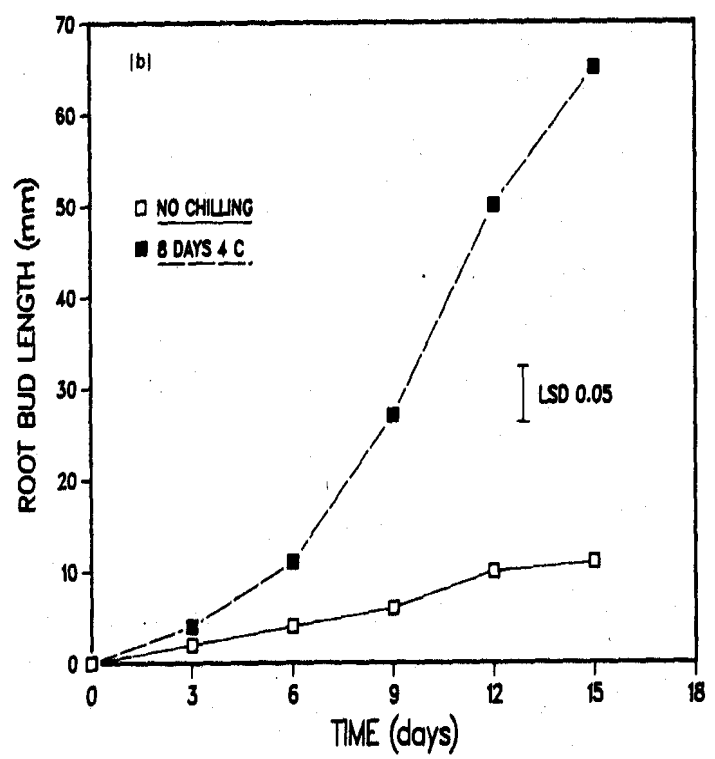




\section{Exogenous auxins}

Root bud growth was significantly higher than the control at $10^{-9}$ and $10^{-11} \mathrm{M}$ IAA, whereas $10^{-3} \mathrm{M}$ IAA completely eliminated root bud elongation (Figure 2). Growth suppression at $10^{-3}$ and $10^{-5} \mathrm{M}$ IAA was similar to that reported by Budd (3). However, Budd did not observe stimulation of leafy spurge root bud growth at $10^{-9} \mathrm{M}$ and did not test a concentration of $10^{-11} \mathrm{M}$ IAA. In addition, Budd applied IAA in $1.5 \%$ agar rather than in aqueous solution, which could account for the difference in response at low concentrations.

Figure 2. Growth response of leafy spurge root buds on 2-cm-long root sections after 9-day exposure to various levels of napthalene-acetic acid and indole-3-acetic acid. Data from four experiments were combined. Bars marked with "*" are significantly different from the control as determined by LSD $(P=$ 0.05).

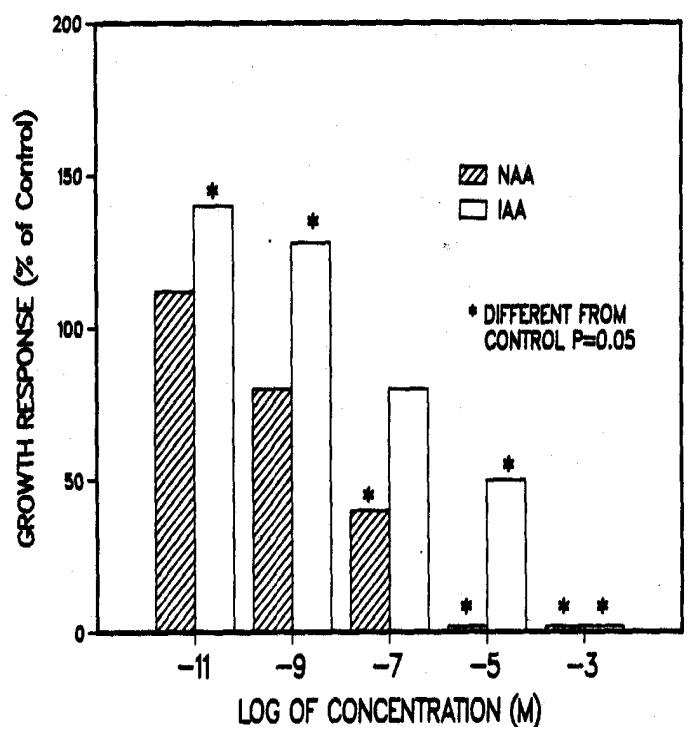

NAA did not significantly increase root bud growth at $10^{-9}$ and $10^{-11}$ or $10^{-13} \mathrm{M}$ (data not shown). NAA eliminated root bud elongation at $10^{-5} \mathrm{M}$, a concentration 100 times lower than IAA concentration required to stop root bud elongation. NAA was found to be significantly more inhibitory than IAA to shoot production in roots of rush skeletonweed (14) and European aspen (8). The physiological basis for this difference is not known; however, a synthetic auxin like NAA may be less susceptible to enzymatic hydrolysis. Differences in rates of conjugation were not likely the cause, since both NAA and IAA applied exogenously are readily conjugated in plant tissue (1).

\section{TIBA experiments}

TIBA applications significantly increased root bud growth in intact plants 10 days after treatment application (Table 3). Stem and root applications resulted in a 14 and 32\% increase in root buds longer than $3 \mathrm{~mm}$, respectively. The response of root buds following combined stem and root treatment was not significantly different than growth following root treatment alone.

Since early reports on the effects of TIBA on basipetal IAA transport (19), this compound and others have been used to indicate the primary role of IAA in correlative control of axillary buds (22). Kefford and Caso (14) demonstrated the ability of TIBA to reverse inhibitory auxin effects on shoot production in rush skeletonweed root sections. 
Eliasson (10) used TIBA applied in lanolin to aspen stems, plus mechanical and steam girdling to demonstrate the role of shoot-produced auxin on bud formation. Our results agree with those of previous investigators and provide additional evidence for the role of shoot-produced IAA in root bud correlative inhibition of leafy spurge.

Table 3. Response of leafy spurge root buds to various applications of TIBA $(1 \mathrm{mM})$. Treatments were applied to intact plants.

\begin{tabular}{lc}
\hline Location of TIBA application & Increase in root buds $>3 \mathrm{~mm}^{\mathrm{a}}$ \\
\hline & $(\%$ control $)$ \\
& $3.2 \mathrm{a}$ \\
Control ${ }^{\mathrm{b}}$ & $14.0 \mathrm{~b}$ \\
Stem & $32.2 \mathrm{c}$ \\
Root & $26.0 \mathrm{c}$ \\
Stem + root & \\
\hline${ }^{\mathrm{a}} \mathrm{Number}$ of root buds longer than $3 \mathrm{~mm}$ was determined before and after treatment application. The differences in \\
starting and ending values were expressed as a percent increase and compared by Newman-Keul's sequential \\
studentized range test $(\mathrm{P}=0.05)$. Means followed by the same letter are not significantly different. \\
${ }^{\mathrm{b}}$ Combination of root and stem treatment controls that were treated in an identical manner but without TIBA.
\end{tabular}

It has been suggested that leafy spurge root buds are quiescent because of internal nutrient and water balances which favor movement of existing resources to the main shoot $(17,18)$. However, root bud growth in a number of perennial plants has been manipulated by exogenous auxin applications $(3,8,11,14)$. In all cases, auxin concentrations between $10^{-5}$ and $10^{-3} \mathrm{M}$ have strongly inhibited adventitious shoot growth. Although these auxin concentrations are probably higher than endogenous levels, our results and those of other investigators $(3,8,11,24)$ indicated inhibition of root bud growth in plants such as leafy spurge results predominantly from hormonal regulation.

Factors such as plant water and nutrient status, day length, and temperature have been shown to affect endogenous hormone levels (12); therefore, the correlation between these factors and root bud growth is not unexpected. Measuring endogenous-free and conjugated IAA levels during the growing season or after experimental manipulation could provide important information about hormonal regulation of root bud growth. Findings from such work might indicate areas of research that would eventually lead to long-term control of leafy spurge and other perennial weeds.

\section{Literature cited}

1. Bandurski, R. S. 1984. Metabolism of indole 3-acetic acid. Pages 183-200 in Crozier and Hillman, eds. The Biosynthesis and Metabolism of Plant Hormones. Cambridge Univ. Press, Cambridge, U.K.

2. Blake, T. J., D. M. Reid, and S. B. Rood. 1983. Ethylene, indoleacetic acid and apical dominance in peas: a reappraisal. Physiol. Plant. 59:481-487.

3. Budd, R. W. 1973. An excellent source of vegetative buds for use in plant hormone studies of apical dominance. Plant Physiol. 52:82-83.

4. Coupland, R. T. and J. F. Alex. 1955. The reproductive capacity of vegetative buds on the underground parts of leafy spurge (Euphorbia esula L.). Can. J. Agric. Sci. 35:477-484.

5. Cuthbertson, E. G. 1972. Chondrilla juncea in Australia IV. Root morphology and regeneration from root fragments. Aust. J. Exp. Agric. Anim. Husb. 12:528-534.

Page 9 of 10 
6. Dore, J. 1953. Seasonal variation in the regeneration of rootcuttings. Nature 172:1189.

7. Dunn, P. H. 1985. Origins of leafy spurge in North America. Pages 7-13 in A. K. Watson, ed. Leafy Spurge. Weed Sci. Soc. Am., Champaign, IL.

8. Eliasson, L. 1961. The influence of growth substances on the formation of shoots from aspen roots. Physiol. Plant. 14:150-156.

9. Eliasson, L. 1971. Growth regulators in Populus tremula. III. Variation of auxin and inhibitor level in roots in relation to root sucker formation. Physiol. Plant. 25:118-121.

10. Eliasson, L. 1971. Growth regulators in Populus tremula. IV. Apical dominance and suckering in young plants. Physiol. Plant. 25:263-267.

11. Emery, A.E.H. 1955. The formation of buds on the roots of Chamaenerion angustifolium (L.) Scop. Phytomorphology 5: 139-145.

12. Goodwin, P. B., B. I. Gollnow, and D. S. Letham. 1978. Phytohormones and growth correlations. Pages 215-249 in D. S. Letham, P. B. Goodwin, and T.J.V. Higgins, eds. Phytohormones and Related Compounds - A Comprehensive Treatise, Elsevier/North Holland Biomedical Press, New York.

13. Hudson, J. P. 1955. Propagation of plants by root cuttings. II. Seasonal fluctuation of capacity to regenerate from roots. J. Hortic. Sci. 30:242-251.

14. Kefford, N. P. and O. H. Caso. 1972. Organ regeneration on excised roots of Chondrilla juncea and its chemical regulation. Aust. J. Biol. Sci. 25:691-706.

15. Lym, R. G. and G. G. Messersmith. 1983. Control of leafy spurge with herbicides. North Dakota Farm Res. 40:16-19.

16. Marston, M. E. and P. J. Village. 1972. Regeneration of raspberries from root cuttings in response to physical treatment of the shoots. Hortic. Res. 12:177-182.

17. McIntyre, G. I. 1972. Developmental studies on Euphorbia esula. The influence of the nitrogen supply on the correlative inhibition of root bud activity. Can. J. Bot. 50:949-956.

18. McIntyre, G. I. 1979. Developmental studies on Euphorbia esula. Evidence of competition for water as a factor in the mechanism of root bud inhibition. Can. J. Bot. 57:2572-2581.

19. Niedergang-Kamien, E. and F. Skoog. 1956. Studies on polarity and auxin transport in plants. I. Modification of polarity and auxin transport by triiodobenzoic acid. Physiol. Plant. 9:60-63.

20. Noble, D. L., P. H. Gunn, and L. A. Andres. 1979. The leafy spurge problem. Pages 8-15 in Proc. Leafy Spurge Symp., Bismark, ND, June 26-27, 1979. North Dakota State Univ. Coop. Ext. Serv. 84 pp.

21. Nooden, L. D. and J. A. Weber. 1978. Environmental and hormonal control of dormancy in terminal buds of plants. Pages 221-268 in M. E. Clutter, ed. Dormancy and Developmental Arrest. Academic Press, New York.

22. Phillips, I. D. J. 1975. Apical dominance. Annu. Rev. Plant Physiol. 26:341- 367.

23. Raju, M V. S., T. A. Steeves, and R. T. Coupland. 1964. On the regeneration of root fragments of leafy spurge (Euphorbia esula L.). Weed Res. 4:2-11.

24. Sanders, P. 1978. Phytohormones and bud dormancy. Pages 423-441 in D. S. Letham, P. B. Goodwin, and T.J.V. Higgins, eds. Phytohormones and Related Compounds - A Comprehensive Treatise. Elsevier/North Holland Biomedical Press, New York.

25. Schier, G. A. 1873. Seasonal variation in sucker production from excised roots of Populus tremuloides and the role of endogenous auxin. Can. J. For. Res. 3:459-461.

26. Selleck, G. W., R. T. Coupland, and C. Frankton. 1962. Leafy spurge in Saskatchewan. Ecol. Monogr. 32:1-29.

27. Sterrett, J. P., W. E. Chappell, and G. M. Shear. 1968. Temperature and annual growth cycle effects on root suckering in black locust. Weed Sci. 16:250-251.

28. Yang, S. F. 1980. Regulation of ethylene biosynthesis. HortScience 15:238-243.

29. Zimmerman, R. H., M. Lieberman, and O. C. Broome. 1977. Inhibitory effect of a rhizobitoxine analog on bud growth after release from dormancy. Plant Physiol. 59:158-160. 